\title{
Enhanced West Nile virus surveillance in the North Kent marshes, UK
}

\author{
Alexander GC Vaux ${ }^{1 *}$, Gabriella Gibson², Luis M Hernandez-Triana ${ }^{3}$, Robert A Cheke ${ }^{2}$, Fiona McCracken ${ }^{3}$, \\ Claire L Jeffries ${ }^{3,4}$, Daniel L Horton ${ }^{3,5}$, Simon Springate ${ }^{2}$, Nicholas Johnson ${ }^{3}$, Anthony R Fooks ${ }^{3,6}$, Steve Leach ${ }^{7}$ \\ and Jolyon M Medlock ${ }^{1,8}$
}

\begin{abstract}
Background: As part of efforts to more fully understand the potential risks posed by West Nile virus (WNV) and Usutu virus (USUV) in the UK, and following on from previous reports of a potential bridge vector Culex modestus for these viruses, at wetland sites in North Kent, mosquito surveillance was undertaken more widely across the Isle of Sheppey, the Hoo Peninsula and the Kent mainland.

Methods: Larval surveys were conducted and Mosquito Magnet ${ }^{\oplus}$ adult traps were used to collect adult mosquitoes. Pools of female mosquitoes were tested for the presence of WNV using real-time reverse transcriptase polymerase chain reaction. A subset of samples was tested for USUV.

Results: Culex modestus was found in both the pre-imaginal and imago stage at all five locations surveyed, accounting for $90 \%$ of adult mosquitoes collected. WNV or USUV were not detected in any sample.

Conclusions: Although no mosquitoes have been shown to be virus positive, the field survey data from this study demonstrated the dominance of an important bridge vector species for WNV in this region. Its wide geographical distribution highlights the need to update risk assessments on WNV introduction, and to maintain vigilance for WNV in the South East of England.
\end{abstract}

Keywords: Culex modestus, United Kingdom, West Nile virus, Usutu virus, Culicidae, Mosquito, Surveillance

\section{Background}

West Nile virus (WNV) has previously been identified as a vector-borne pathogen of concern to UK public and veterinary health $[1,2]$. The presence of WNV in the UK has not been recorded, despite surveillance in humans, horses, and wild birds $[3,4]$, but serological studies of resident and migratory birds have reported virus-specific neutralizing antibodies to WNV, Usutu virus (USUV) and Sindbis viruses (SINV) [5]. Transmission of the virus to humans and horses is reliant upon competent bridge vectors transmitting the virus from an enzootic bird-mosquito-bird cycle to bird-mosquito-human/horse transmission, where humans and horses are dead-end hosts [6,7]. Thirty four species of mosquito have been recorded in the British Isles, nine of which have been

\footnotetext{
*Correspondence: Alex.Vaux@phe.gov.uk

${ }^{1}$ Medical Entomology group, MRA, Emergency Response Department, Public Health England, Porton Down, Salisbury SP4 OJG, UK

Full list of author information is available at the end of the article
}

implicated in WNV transmission elsewhere $[1,2,8]$. The main competent bridge vectors in continental Europe are Culex pipiens molestus, $C x$. perexiguus and $C x$. modestus $[9,10]$. Of these taxa, the UK has localised populations of Cx. pipiens biotype molestus, which can be a human biting nuisance and $C x$. modestus. However, there are no populations of $C x$. perexiguus which currently has a distribution restricted to warmer climates in the Mediterranean, North Africa and Asia. Until recently, Cx. modestus had not been recorded in the UK since the 1940s when three adults and ten larvae were found and eradicated in Portsmouth [11]; however, it has recently been reported in significant numbers at three locations in North Kent [12], and also recorded in lower numbers Cambridgeshire and Dorset [13].

Golding et al. [12] identified the presence of Cx. modestus at three sites on the Hoo Peninsula in North Kent, and the species was found in significant numbers both as larvae and as trap-caught adults. A total of 679

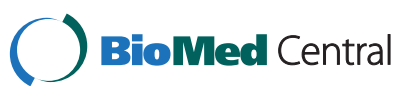

(c) 2015 Vaux et al.; licensee BioMed Central. This is an Open Access article distributed under the terms of the Creative Commons Attribution License (http://creativecommons.org/licenses/by/4.0), which permits unrestricted use, distribution, and reproduction in any medium, provided the original work is properly cited. 
Cx. modestus adults were collected over twenty trap nights at Northward Hill, on the Hoo Peninsula, (AprilOctober), at a mean count per night of 33.95, representing $75 \%$ of the total catch. Culex modestus is considered to be the principal vector of WNV in parts of Europe, where it is found in a range of wetland habitats including reedbeds and rice fields, and is known to aggressively feed on birds, and mammals including humans $[14,15]$ The occurrence of this species in the North Kent marshes in habitats frequented by migratory birds and grazing horses is a consideration when conducting surveillance for WNV. Furthermore, a principal enzootic vector, $C x$. pipiens pipiens is common in the UK, and therefore the co-existence of these two species in North Kent would increase the risk for transmission of the virus should it occur there, to horses and humans if WNV were introduced.

The study aimed to confirm the persistence and map the extent of the distribution of $C x$. modestus, and combine ongoing entomological surveillance $[12,13]$ and WNV surveillance in wildlife [3] to better inform the risk assessment and identification of risk areas.

\section{Methods}

\section{Mosquito survey}

Following previous surveys that identified the presence of the vector $C x$. modestus at Elmley Marshes $\left(51^{\circ} 22^{\prime}\right.$ $\left.25^{\prime \prime} \mathrm{N}, 0^{\circ} 46^{\prime} 51^{\prime \prime} \mathrm{E}\right)$, Northward Hill Nature Reserve $\left(51^{\circ}\right.$ $\left.23^{\prime} 47^{\prime \prime} \mathrm{N}, 0^{\circ} 42^{\prime} 36^{\prime \prime} \mathrm{E}\right)$, and Cliffe Marshes $\left(51^{\circ} 27^{\prime} 48^{\prime \prime} \mathrm{N}, 0^{\circ}\right.$ $33^{\prime} 2$ "E) [12], a site visit of potential larval habitats was conducted during 2012 using maps and field visits. In May 2013 an initial field survey was conducted to identify sites across North Kent, and nine sites were chosen for larval surveys: the previously surveyed sites at Cliffe Marshes, Northward Hill and Elmley Marshes, and additional sites at Allhallows Marshes $\left(51^{\circ} 27^{\prime} 60^{\prime \prime} \mathrm{N}, 0^{\circ} 39^{\prime}\right.$ $\left.19^{\prime \prime} \mathrm{E}\right)$, Chetney Marshes $\left(51^{\circ} 27^{\prime} 48^{\prime} \mathrm{N}, 0^{\circ} 33^{\prime} 2^{\prime \prime} \mathrm{E}\right)$, Oare Marshes $\left(51^{\circ} 20^{\prime} 34^{\prime \prime} \mathrm{N}, 0^{\circ} 53^{\prime} 20^{\prime \prime} \mathrm{E}\right)$, Graveney Marshes $\left(51^{\circ} 20^{\prime} 5^{\prime \prime} \mathrm{N}, 0^{\circ} 55^{\prime} 55^{\prime \prime} \mathrm{E}\right)$, and the Harty Marshes $\left(51^{\circ} 22^{\prime}\right.$ 1 'N, $\left.0^{\circ} 55^{\prime} 12^{\prime \prime} \mathrm{E}\right)$. After a further larval survey at Allhallows Marshes and Harty Marshes it was decided not to take samples at these locations due to the absence of suitable aquatic habitats. Furthermore, owing to difficult access at Graveney Marshes, no further surveys were conducted there.

Larval surveys were conducted at the remaining five sites (Figure 1) every two weeks from $1^{\text {st }}$ July 2013 to $19^{\text {th }}$ August 2013. Approximately 25 larval sampling points were chosen at each site. Three $250 \mathrm{ml}$ dips were taken at each sampling point and pre-imaginal stages (I-III, IV instar larvae, pupae) were collected and identified using the keys of Schaffner et al. [16]. No attempt was made to differentiate between $C x$. pipiens s.l. and $C x$. torrentium, as larvae were not reared to IV instar, and males were not collected. Therefore, $C x$. pipiens s.l. and $C x$. torrentium are referred to as $C x$. pipiens s.l./Cx. torrentium. The Anopheles maculipennis species complex was not identified further to species (referred to as

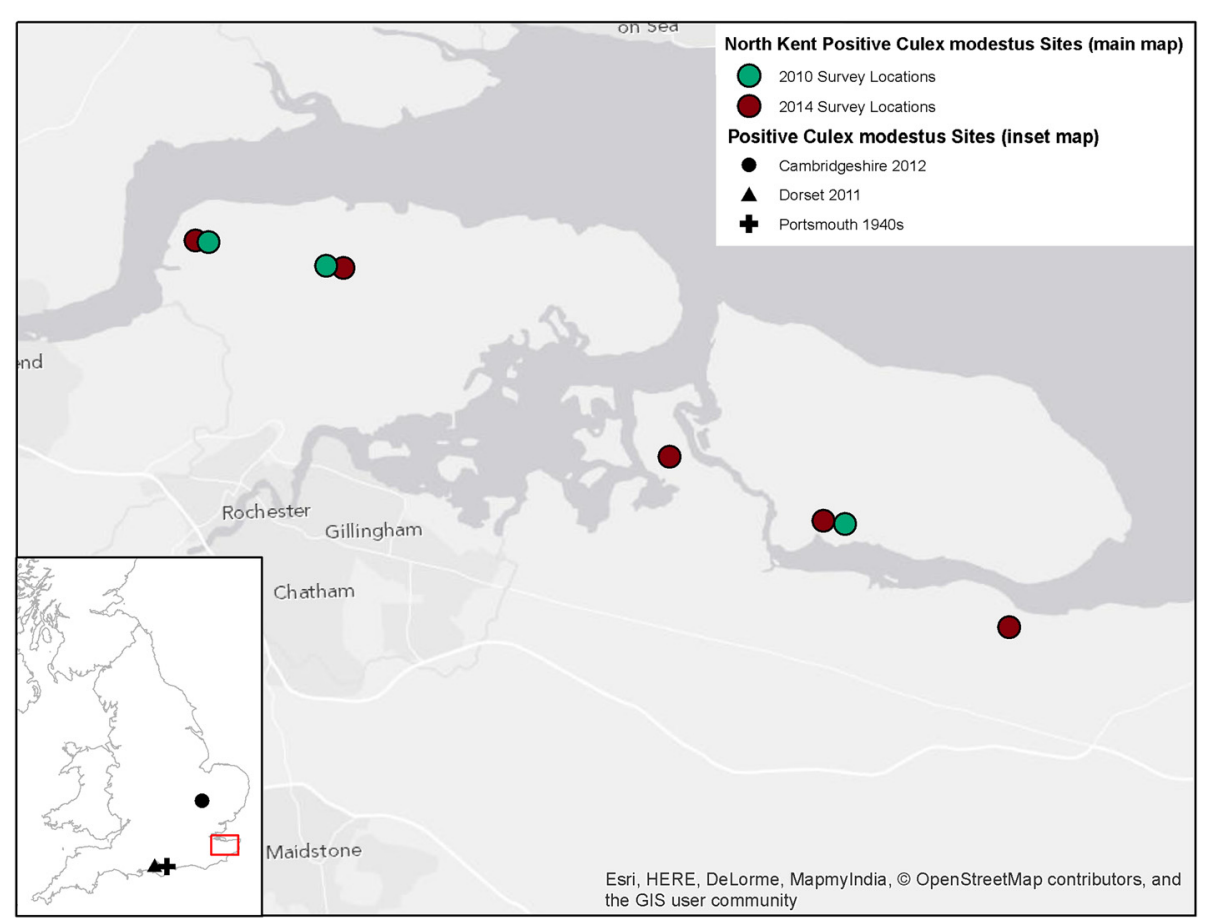

Figure 1 Map of the survey locations and historical records. 
An. maculipennis s.l.) which would have required DNA analyses. The latter was not deemed necessary given that this project was focused on $C x$. modestus.

Adult trapping was conducted using the Mosquito Magnet $^{\circ}$ Executive Mosquito trap (MosquitoMagnet, Lititz, Pennsylvania, USA; http://www.mosquitomagnet. $\mathrm{com} /$ ) with Octenol (MosquitoMagnet, Lititz, Pennsylvania, USA; http://www.mosquitomagnet.com/). This trap was chosen given its proven ability to collect large numbers of the target species, $C x$. modestus [12] and the ability of the trap to run for a number of nights without interruption, servicing or maintenance. It has also been proven to collect large numbers of British mosquitoes [17,18]. Other traps including $\mathrm{CO}_{2}$ light traps were considered, but given their reliance on batteries and the frequency required to service them, they were not chosen. Traps were run from Monday to Thursday (3 nights) every other week at Cliffe Marshes, Northward Hill, Chetney Marshes, Elmley Marshes and Oare Marshes. Traps at Cliffe and Northward Hill ran on alternate weeks from week 29-37, and traps at Chetney, Elmley and Oare Marshes ran on alternate weeks from week 30-38. Two traps were run at Elmley given the size of the site and the confirmed presence of the species in previous surveys. Adult mosquitoes were removed from traps, placed on dry ice and transported to the laboratory to be identified on a cold plate of dry ice. Samples were kept at $-80^{\circ} \mathrm{C}$ until viral testing. Mosquito abundance was calculated per litre for larvae $\left(\mathrm{L}^{\mathrm{s}}\right)$, and per trap night for adults, and expressed as mean number of adults per night over the season $\left(\mathrm{n}^{\mathrm{s}}\right)$.

\section{Virus testing}

Adult females of target species were separated in pools of ten specimens per tube whenever possible, placed in disruption tubes and sent to the Animal and Plant Health Agency (APHA) for molecular analysis for virus detection. Tissue disruption of the whole specimen, homogenization and RNA extraction was undertaken using a Qiagen RNeasy Mini Kit. Two pre-treated $5 \mathrm{~mm}$ stainless steel beads were placed in each $2 \mathrm{ml}$ disruption microtube containing the pooled sample. Each tube was homogenized dry for $3 \mathrm{~min}$ at $25 \mathrm{~Hz}$ in the TissueLyser (Qiagen) and then centrifuged for $3 \mathrm{~min}$ at full speed $(12,100 \times \mathrm{g})$. Half of the pellets that formed were placed in cell culture medium (Medium (E-MEM/10\%FBS) for cell culture/virus isolation, if needed. Immediately $600 \mu \mathrm{l}$ of buffer RLT (Qiagen) was dispensed to each tube, vortexed and centrifuged. Without disturbing any visible pellet, the supernatant was transferred from the disruption tube to a $1.5 \mathrm{ml}$ collection tube and kept at $-20^{\circ} \mathrm{C}$. RNA was extracted from mosquito homogenates using Qiagen RNeasy Mini kit as per the manufacturer's instructions. RNA was eluted in $50 \mu \mathrm{l}$ of nucleasefree water.
Mosquito RNA samples were screened for the presence of WNV and USUV virus using $2 \mu \mathrm{l}$ of the total RNA extract and employing probe-based PCR techniques in Mx3000P real time PCR systems (Stratagene). Published methods for the detection of WNV RNA were followed [19]. This primer set amplifies a conserved region of the 5'-UTR and part of the capsid gene producing a product of approximately 144 base pairs. The RT-PCR was carried out in a $50 \mu \mathrm{l}$ reaction volume containing: nuclease-free water; $2 \times$ RT-PCR reaction mix for probes (BioRad); WNV Linke FOR primer (5pmol) $(1 \mu \mathrm{l})$; WNV Linke REV primer (5pmol) $(1 \mu \mathrm{l})$; WNV Linke probe $(2.5 \mathrm{pmol})(1 \mu \mathrm{l})$; and iScript RT for one step RT-PCR (BioRad). PCR thermal amplification conditions were used as previously published [19]. A notemplate control and a WNV positive RNA sample (strain goose Israel 1998) were included on every test plate.

For the detection of USUV RNA the primers and probe of Jöst et al. [20] were used. These oligonucleotides are directed at the NS1gene of USUV and amplify a fragment approximately 91 base pair in length. The RT PCR was carried out in a $25 \mu \mathrm{l}$ reaction volume containing: RNase-free water; $2 x$ QuantiTect RT-PCR Master mix; Jost USUV Primer mix $(10 \mu \mathrm{M}$ primer/1.25 $\mu \mathrm{M}$ probe) and QuantiTect RT mix (Qiagen). A no-template control and a USUV positive RNA sample (strain Arb153) were included on every test plate.

\section{Results}

\section{Mosquito survey}

Eleven species (Anopheles claviger, An. maculipennis s.l., An. plumbeus, Coquillettidia richiardii, Ochlerotatus caspius, Oc. dorsalis, Oc. detritus, Oc. flavescens, Culex pipiens s.l./Cx. torrentium, Cx. modestus and Culiseta annulata) were identified in the six adult traps across the five sites. Culex modestus was found at all traps and at all larval sites.

In total, 5724 adults were trapped over 75 trap nights at a mean abundance of $19.07 / \mathrm{n}^{\mathrm{s}}$ (Table 1). Culex modestus was the most abundant species (5216/5724; 91\%; $\left.17.39 / \mathrm{n}^{\mathrm{s}}\right)$, thereafter $C q$. richiardii $\left(\mathrm{n}=220,0.73 / \mathrm{n}^{\mathrm{s}}\right)$, Cx. pipiens s.l./Cx. torrentium $\left(\mathrm{n}=164,0.54 / \mathrm{n}^{\mathrm{s}}\right)$ and An. maculipennis s.l. $\left(\mathrm{n}=46,0.15 / \mathrm{n}^{\mathrm{s}}\right)$. The remaining species were trapped in lower numbers: An. claviger $\left(0.12 / \mathrm{n}^{\mathrm{s}}\right)$, Oc. flavescens $\left(0.05 / \mathrm{n}^{\mathrm{s}}\right)$, Oc. detritus $\left(0.03 / \mathrm{n}^{\mathrm{s}}\right)$, Cs. annulata $\left(0.03 / \mathrm{n}^{\mathrm{s}}\right)$, Oc. dorsalis $\left(0.01 / \mathrm{n}^{\mathrm{s}}\right)$, Oc. caspius $\left(0.003 / \mathrm{n}^{\mathrm{s}}\right)$, An. plumbeus $\left(0.003 / \mathrm{n}^{\mathrm{s}}\right)$.

The highest adult abundances across the season were found at Cliffe Marshes $\left(44.4 / \mathrm{n}^{\mathrm{s}}\right)$, Elmley Barn $\left(22.0 / \mathrm{n}^{\mathrm{s}}\right)$, Chetney $\left(16.11 / \mathrm{n}^{\mathrm{s}}\right)$ and Northward Hill $\left(13.45 / \mathrm{n}^{\mathrm{s}}\right)$, with lower adult abundances at Elmley field $\left(5.97 / \mathrm{n}^{\mathrm{s}}\right)$ and Oare $\left(3.89 / \mathrm{n}^{\mathrm{s}}\right)$ (Figure 2).The proportion of mean adult Cx. modestus per trap night to total mean adults trapped per night ranged between $76 \%$ and $96 \%$ across the sites. 
Table 1 Adult data shown for species (Cx. modestus, An. maculipennis s.l., Cx. pipiens s.l./Cx. torrentium, Cq. richardii), and sites (Chetney, Cliffe, Elmley Field and Elmley Barn, Northward Hill, and Oare), shown by mean number of adults per night over the season $\left(n^{s}\right)$

\begin{tabular}{|c|c|c|c|c|c|c|}
\hline Site & $\begin{array}{l}\text { Total number } \\
\text { adult females }\end{array}$ & $\begin{array}{l}\text { All species } \\
\left(n^{s}\right) \pm S E\end{array}$ & $\begin{array}{l}\text { Mean Cx. modestus } \\
\left(n^{s}\right) \pm S E\end{array}$ & $\begin{array}{l}\text { Mean An. maculipennis } \\
\text { s.l. }\left(n^{s}\right) \pm S E\end{array}$ & $\begin{array}{l}\text { Mean CX. pipiens s.I./CX. } \\
\text { torrentium }\left(n^{s}\right) \pm S E\end{array}$ & $\begin{array}{l}\text { Mean Cq. richiardii } \\
\left(n^{s}\right) \pm S E\end{array}$ \\
\hline Chetney & 918 & $16.11 \pm 7.57$ & $12.75 \pm 7.70$ & $0.02 \pm 0.02$ & $2.40 \pm 1.70$ & $0.68 \pm 0.46$ \\
\hline Cliffe & 2795 & $44.4 \pm 24.1$ & $41.90 \pm 24.3$ & $0.05 \pm 0.03$ & $0.03 \pm 0.03$ & $2.00 \pm 1.61$ \\
\hline Elmley barn & 922 & $22.0 \pm 15.5$ & $21.2 \pm 15.6$ & $0.31 \pm 0.18$ & $0.14 \pm 0.14$ & $0.19 \pm 0.17$ \\
\hline Elmley field & 179 & $5.97 \pm 4.28$ & $4.97 \pm 4.39$ & $0.37 \pm 0.21$ & $0.33 \pm 0.17$ & $0.30 \pm 0.30$ \\
\hline Northward & 686 & $13.34 \pm 7.57$ & $12.55 \pm 7.65$ & $0.28 \pm 0.13$ & $0.06 \pm 0.04$ & $0.49 \pm 0.47$ \\
\hline Oare & 222 & $3.89 \pm 1.39$ & $2.98 \pm 1.47$ & $0.07 \pm 0.04$ & $0.11 \pm 0.08$ & $0.23 \pm 0.16$ \\
\hline All sites & 5724 & $19.07 \pm 5.91$ & $17.39 \pm 5.95$ & $0.15 \pm 0.04$ & $0.55 \pm 0.38$ & $0.73 \pm 0.36$ \\
\hline
\end{tabular}

The greatest abundances of adult mosquitoes were found during the mid-August trap weeks (Figure 3).

The larval surveys yielded five species: An. claviger, An. maculipennis s.l., Cx. modestus, Cx. pipiens s.l./Cx. torrentium, and Cs. annulata (Figure 4). Over the course of the survey, $7.36 / \mathrm{L}^{\mathrm{s}}$ (3945 total larvae) were collected, dominated by two species $C x$. modestus $\left(7.36 / \mathrm{L}^{\mathrm{s}}\right)$ and $C x$. pipiens s.l./Cx. torrentium $\left(2.53 / \mathrm{L}^{\mathrm{s}}\right)$. A third classification of Culex sp. $\left(1.56 / \mathrm{L}^{\mathrm{s}}\right)$ was made on account of the difficulty in separating I \& II instar larvae of this genus. Anopheles maculipennis s.l. $\left(0.80 / \mathrm{L}^{\mathrm{s}}\right)$ was more abundant than An. claviger $\left(0.004 / \mathrm{L}^{\mathrm{s}}\right)$, and Cs. annulata $\left(0.086 / \mathrm{L}^{\mathrm{s}}\right)$.

The highest immature abundances across all species were reported at Chetney marshes $\left(17.05 / \mathrm{L}^{\mathrm{s}}\right)$ and Cliffe marshes $\left(12.48 / \mathrm{L}^{\mathrm{s}}\right)$, with lower abundances at Elmley marshes $\left(3.81 / \mathrm{L}^{\mathrm{s}}\right)$, Oare marshes $\left(3.18 / \mathrm{L}^{\mathrm{s}}\right)$ and Northward Hill $\left(1.64 / \mathrm{L}^{\mathrm{s}}\right)$. The highest mean number of $C x$. modestus was recorded at Cliffe and Chetney Marshes (Table 2).

\section{Virus testing}

The RT PCR for WNV did not detect the presence of WNV RNA in any Culex modestus samples (282 pools; 2290 female specimens; Table 3). In addition, a panel of 125 samples of $C x$. modestus (1025 females) was also tested to detect the presence of USUV virus RNA. There was no product amplification of USUV RNA in any sample. The presence of WNV was also tested in a further eight species (24 pools; 113 specimens; Table 3). In all samples RNA was not detected by real time RT-PCR.

\section{Discussion}

Culex modestus was identified at all sites where larval and adult surveys were conducted; it was found to be the dominant species trapped by the Mosquito Magnet ${ }^{\oplus}$ at all of the sites, and in larval surveys it was proven to be as abundant as the ubiquitous species $C x$. pipiens s.l./Cx. torrentium. Culex modestus dominated the species

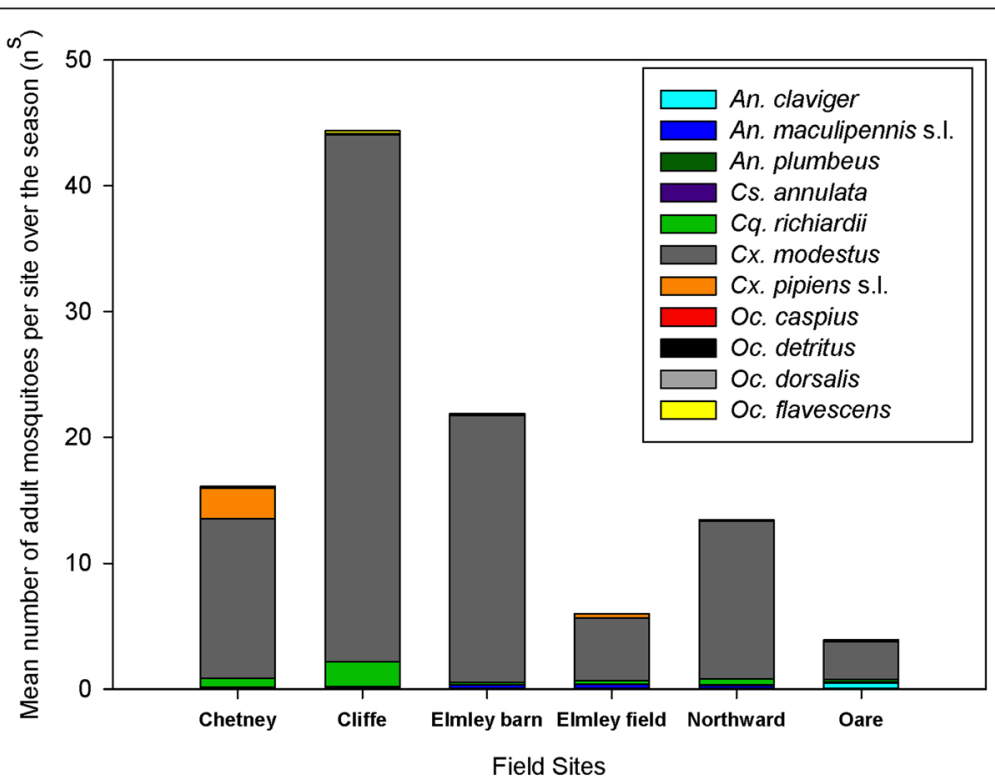

Figure 2 The abundance of adult mosquitoes by species at Chetney, Cliffe, Elmley, Northward Hill and Oare Marshes. Mosquito Magnets were run for three nights during five weeks from July to September 2013. 


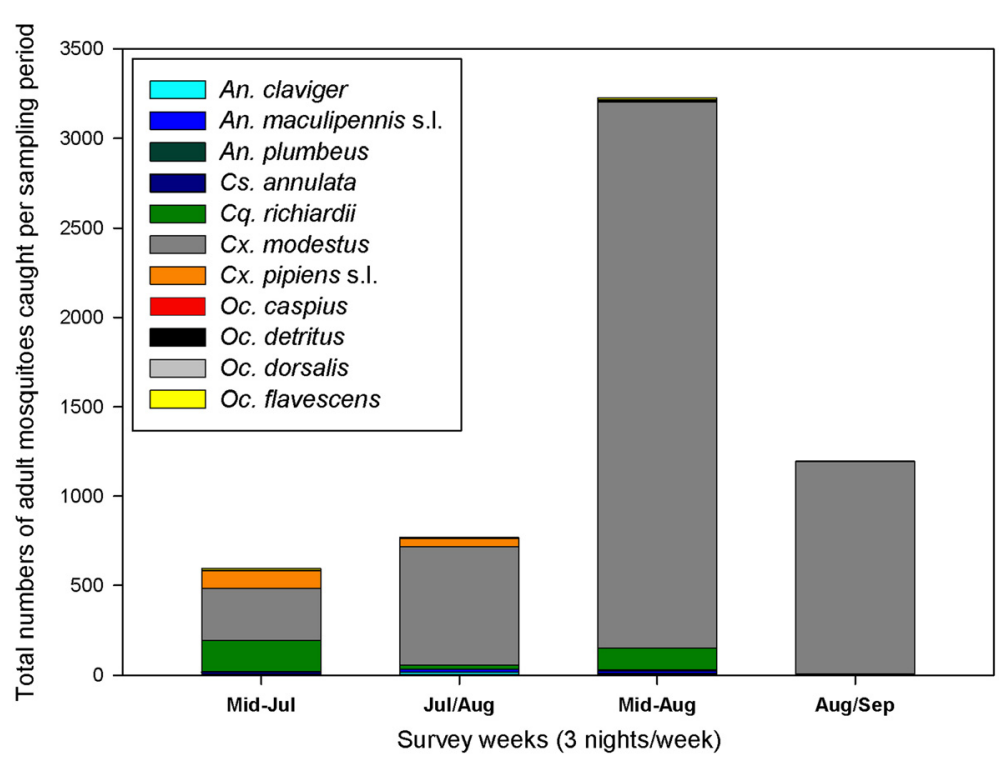

Figure 3 The abundance of adult mosquitoes by species shown by temporal categories: Mid-Jul; Jul/Aug; Mid-Aug, and Aug/Sep.

composition trapped at Northward Hill, representing 93\% of the total adults caught, which is even higher than the results of adult trapping during 2010 when the species accounted for $75 \%$ of the total adult catch [12]. In a previous study, comparing the CDC light trap and Mosquito Magnet traps at Elmley Marshes, Cx. modestus was not recorded, however $C x$. pipiens s.l. and $C x$. torrentium were [17].

The Mosquito Magnet ${ }^{\oplus}$ uses Octenol lures, which selectively attract mammal-biting species, and explains the lack of Culex pipiens s.1./Cx. torrentium adults caught at traps where larval surveys indicated a high population of the species. The trap at Chetney was the only trap to catch significant numbers of $C x$. pipiens s.l./Cx. torrentium (137 adults over the season; $<10$ adults at all other sites), which is an unusual finding, and differs from previous results when no $C x$. pipiens s.l./Cx. torrentium were trapped at the Isle of Sheppey using Mosquito Magnets [17]. Mosquito Magnets have been used extensively in habitats with high densities of $C x$. pipiens

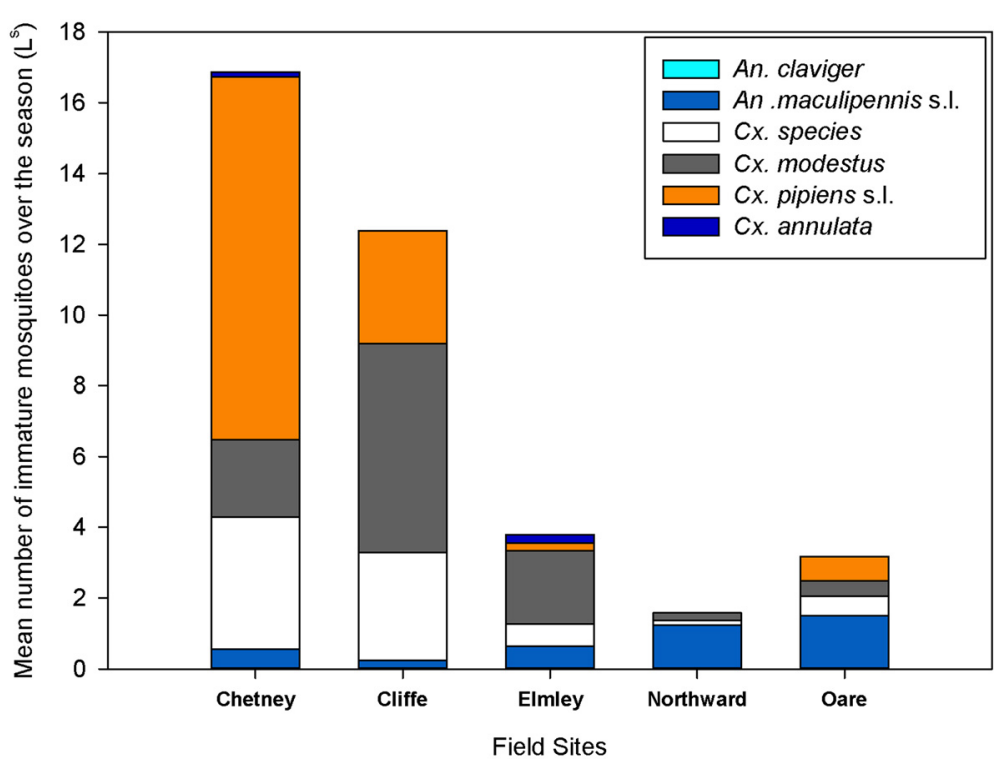

Figure 4 The abundance of immature mosquitoes by species at Chetney, Cliffe, Elmley, Northward Hill and Oare Marshes. 
Table 2 Larvae data shown for species (Cx. modestus, An. maculipennis s.I., Cx. pipiens s.I./Cx. torrentium, Cx. species), and sites (Chetney, Cliffe, Elmley, Northward Hill and Oare)

\begin{tabular}{|c|c|c|c|c|c|c|c|c|}
\hline Site & $\begin{array}{l}\text { Number } \\
\text { sampling } \\
\text { points } \\
(3 \times 250 \mathrm{ml}) \\
\end{array}$ & $\begin{array}{l}\text { Water } \\
\text { surveyed } \\
\text { (litres) }\end{array}$ & $\begin{array}{l}\text { Total } \\
\text { number } \\
\text { larvae }\end{array}$ & $\begin{array}{l}\text { Mean larvae } \\
\text { per litre } \\
\left(L^{s}\right) \pm S E\end{array}$ & $\begin{array}{l}\text { Mean } C x . \\
\text { modestus per } \\
\text { litre }\left(L^{s}\right) \pm S E\end{array}$ & $\begin{array}{l}\text { Mean } A n . \\
\text { maculipennis s.I. } \\
\text { per litre }\left(L^{s}\right) \pm S E\end{array}$ & $\begin{array}{l}\text { Mean } C x . \text { pipiens } \\
\text { s.I./Cx. torrentium } \\
\text { per litre }\left(L^{s}\right) \pm S E\end{array}$ & $\begin{array}{l}\text { Mean } C x . \\
\text { species per } \\
\text { litre }\left(L^{s}\right) \pm S E\end{array}$ \\
\hline Chetney & 114 & 85.5 & 1458 & $17.05 \pm 5.51$ & $2.20 \pm 0.62$ & $0.55 \pm 0.17$ & $10.25 \pm 4.33$ & $3.73 \pm 3.56$ \\
\hline Cliffe & 154 & 115.5 & 1442 & $12.48 \pm 2.04$ & $5.91 \pm 1.74$ & $0.24 \pm 0.06$ & $3.20 \pm 0.88$ & $3.04 \pm 1.02$ \\
\hline Elmley & 193 & 144.75 & 552 & $3.81 \pm 0.50$ & $2.07 \pm 0.46$ & $0.63 \pm 0.17$ & $0.22 \pm 0.06$ & $0.62 \pm 0.22$ \\
\hline Northward & 97 & 72.75 & 119 & $1.64 \pm 0.31$ & $0.21 \pm 0.10$ & $1.22 \pm 0.30$ & $0.00 \pm 0.00$ & $0.14 \pm 0.09$ \\
\hline Oare & 157 & 117.75 & 374 & $3.18 \pm 0.34$ & $0.43 \pm 0.12$ & $1.50 \pm 0.28$ & $0.69 \pm 0.24$ & $0.55 \pm 0.15$ \\
\hline All sites & 715 & 536.25 & 3945 & $7.36 \pm 1.01$ & $2.31 \pm 0.41$ & $0.80 \pm 0.09$ & $2.53 \pm 0.73$ & $1.56 \pm 0.61$ \\
\hline
\end{tabular}

s.l./Cx. torrentium across the UK and very low numbers of this species have been trapped when using the Octenol lure [18]. This may warrant further investigation of the species trapped here, as it could be a hybrid form of the ornithophagic $C x$. pipiens biotype pipiens and the anthropophagic stenogamic $C x$. pipiens biotype molestus. However it was noted that there was a partridge feeder nearby to the Mosquito Magnet, and therefore it is possible that the Cx. pipiens s.l./Cx. torrentium were inadvertently drawn into the trap. It is worth noting that the distribution of $C x$. torrentium in the UK is poorly understood due to its close morphological similarity to $C x$. pipiens s.l., and given that $C x$. torrentium has also been implicated as an important WNV vector, further studies to more fully understand this species are needed in the UK.

Through the use of rapid, specific RT-PCR assays we were unable to detect WNV or USUV RNA within any of the mosquito samples tested. This corroborates the absence of WNV through surveillance in birds, conducted by APHA (formerly Animal Health and Veterinary Laboratories Agency) since 2001 [3,4]. However it should

Table 3 Number of genera, species and specimens of female Culex modestus and other mosquito species tested for WNV and USUV collected at Kent marshes

\begin{tabular}{lll}
\hline Species & Pools & No. of mosquitoes \\
\hline An. claviger & 3 & 8 \\
An. maculipennis s.l. & 3 & 9 \\
Cq. richardii & 8 & 55 \\
C. annulata & 2 & 3 \\
CX. modestus & 282 & 2290 \\
CX. pipiens s.l./CX. torrentium & 1 & 2 \\
Oc. caspius & 1 & 1 \\
Oc. dorsalis & 1 & 1 \\
Oc. flavescens & 5 & 34 \\
All species & $\mathbf{3 0 6}$ & $\mathbf{2 4 0 3}$ \\
\hline
\end{tabular}

be noted that in regions with high circulation of WNV, many thousands of mosquitoes are routinely tested, and therefore the numbers of samples tested in this study are relatively low for this type of virus testing. Further virus surveillance will need to maximise the number of mosquitoes made available for testing and methods to streamline this process will need to be considered.

\section{Conclusion}

Culex modestus is well established in the ditch habitats that were surveyed at these sites across North Kent, and the results suggest that the species may well be found further east and west along the coastline as defined by suitable habitat. Initial surveys were made to identify suitable habitat further east, and whilst these surveys were not exhaustive, no suitable habitat was identified. This survey recorded a significant population of $C x$. modestus, and given the likelihood of this species being found further afield, further surveys were conducted in 2014. These surveys have identified a wider distribution of the species, finding it as far west as Swanscombe (Gravesend, Kent), as far east as Canterbury (Kent), and also in East Tilbury and Pitsea (Essex) north of the Thames [21]. It is very likely that the species is found further afield, including further into Essex, and into Greater London as suitable habitats permit. Given a lack of historical survey data from many of these areas it is not possible to conclude whether the species has always been present, or has recently spread there. However, earlier, studies on the Hoo Penninsula near Cliffe Marshes and Northward Hill sites, and also at Elmley Marshes did not report the presence of this species $[17,22]$. The species has been reported to be highly impacted by anthropogenic environmental change in the Camargue, France [23], and in the Czech Republic it is now widely distributed and abundant having been found rarely in previous decades [24]. The species has also recently been reported for the first time in Denmark [25]. Within this context, the range and dominance of this 
species appears to be increasing in relation to other species in the UK. The study has further developed collection methods and assays for pathogen surveillance in mosquitoes in a UK context, and further work will aim to continue to develop this capability. Mosquito surveillance is an important addition to surveillance in wild birds, horses, and humans. This study also demonstrates a 'One Health' approach to zoonotic disease surveillance in the UK by integrating public health, veterinary health and academia.

As the principal bridge vector identified in European WNV cycles, the abundance of $C x$. modestus together with populations of the enzootic vector $C x$. pipiens s.l. in extensive habitats supporting resident and migratory birds is an important finding when considering the potential for WNV transmission in southern England. Abundant $C x$. modestus populations in wetland areas with large avian populations, particularly migratory birds, and co-incident with livestock and horses are ecosystems at increased risk of WNV introduction and maintenance [26]. This survey suggests that WNV and USUV are not currently present in wetland sites in South-East England. However, the conditions for virus introduction are present in these areas and the spread of both viruses in Europe in recent years suggests that further monitoring is advisable.

\section{Competing interests}

The authors declare that they have no competing interests.

\section{Authors' contributions}

AGCV, JMM, DLH, ARF, and NJ designed the study. SL, ARF and DLH sourced the funding. AGCV, JMM, GG, RAC and SS conducted the fieldwork. LMHT, FM and CLJ performed the virus testing. AGCV, JMM, LMHT, NJ, SL and GG collaborated in writing the manuscript. All authors read and approved the final manuscript.

\section{Acknowledgements}

We thank the landowners and reserve managers for their permission to access and collect mosquitoes. We are grateful to Maximilian J. Colvin and Samuel J.M. Colvin for assisting in the field. Funding was provided by Defra grants SV3040, SE4215 and SE4112. JM's time was part-funded by the National Institute for Health Research Health Protection Research Unit (NIHR HPRU) in Emerging and Zoonotic Infections at the University of Liverpool in partnership with Public Health England (PHE) and the Liverpool School of Tropical medicine. The views expressed are those of the author(s) and not necessarily those of the NHS, the NIHR, the Department for Environment, Food, and Rural Affairs, Animal and Plant Health Agency, the Department of Health or Public Health England.

\footnotetext{
Author details

${ }^{1}$ Medical Entomology group, MRA, Emergency Response Department, Public Health England, Porton Down, Salisbury SP4 OJG, UK. ${ }^{2}$ Natural Resources Institute, University of Greenwich at Medway Central Avenue, Chatham Maritime, Kent ME4 4TB, UK. ${ }^{3}$ Animal and Plant Health Agency, Wildlife Zoonoses and Vector-Borne Diseases Research Group, Woodham Lane, Addlestone, Surrey KT15 3NB, UK. ${ }^{4}$ Current address: Department of Disease Control, London School of Hygiene and Tropical Medicine, Keppel Street, London WC1E 7HT, UK. ${ }^{5}$ School of Veterinary Medicine, University of Surrey, Guildford, UK. ${ }^{6}$ Institute of Infection and Global Health, University of Liverpool, Liverpool L69 7BE, UK. ${ }^{7}$ Microbial Risk Assessment and Behavioural Science, Emergency Response Department, Public Health England, Porton Down, Salisbury SP4 0JG, UK. ${ }^{8}$ NIHR Health Protections Research Unit in Emerging and Zoonotic Infections, Porton Down, UK.
}

Received: 31 October 2014 Accepted: 29 January 2015

Published online: 10 February 2015

\section{References}

1. Medlock JM, Snow KR, Leach S. Potential transmission of West Nile virus in the British Isles: an ecological review of candidate mosquito bridge vectors. Med Vet Entomol. 2005;19:2-21.

2. Medlock JM, Snow KR, Leach S. Possible ecology and epidemiology of medically important mosquito-borne arboviruses in Great Britain. Epidemiol Infect. 2007;135:466-82.

3. Brugman VA, Horton DL, Phipps LP, Johnson N, Cook AJC, Fooks AR, et al. Epidemiological perspectives on West Nile virus surveillance in wild birds in Great Britain. Epidemiol Infect. 2013;141:1134-42.

4. Phipps LP, Duff JP, Holmes JP, Gough RE, McCracken F, Mcelhinney LM, et al. Surveillance for West Nile virus in British birds (2001 to 2006). Vet Rec. 2008;162:413-5.

5. Buckley A, Dawson A, Moss SR, Hinsley SA, Bellamy PE, Gould EA. Serological evidence of West Nile virus, Usutu virus and Sindbis virus infection of birds in the UK. J Gen Virol. 2003;84(Pt 10):2807-17.

6. Deubel V, Zeller H. West Nile virus. In: Service MW, editor. Encycl ArthropodTransmitted Infect. Wallingford, U.K: CABI Publishing; 2001. p. 563-70.

7. Malkinson M, Banet C. The role of birds in the ecology of West Nile virus in Europe and Africa. Curr Top Microbiol Immunol. 2002;267:309-22.

8. Medlock JM, Vaux AGC. Aedes (Aedes) geminus Peus (Diptera, Culicidae) - an addition to the British mosquito fauna. Dipterists Digest (Second Series). 2009;16:1-4

9. Balenghien T, Vazeille M, Grandadam M, Schaffner F, Zeller $H$, Reiter $P$, et al. Vector competence of some French Culex and Aedes mosquitoes for West Nile virus. Vector Borne Zoonotic Dis. 2008;8:589-95.

10. Muñoz J, Ruiz S, Soriguer R, Alcaide M, Viana DS, Roiz D, et al. Feeding patterns of potential West Nile virus vectors in south-west Spain. PLoS One. 2012;7:e39549.

11. Marshall JF. Records of Culex (Barraudius) modestus Ficalbi (Diptera, Culicidae) obtained in the South of England. Nature. 1945;156:172-3.

12. Golding N, Nunn MA, Medlock JM, Purse BV, Vaux AGC, Schäfer SM. West Nile virus vector Culex modestus established in southern England. Parasit Vectors. 2012;5:32

13. Medlock JM, Vaux AGC. Distribution of West Nile virus vector, Culex modestus, in England. Vet Rec. 2012;171:278.

14. Mouchet J, Rageau J, Laumond C, Hannoun C, Beytout D, Oudar J, et al. Epidemiology of West Nile virus: study of a focus in Camargue. V. The vector: Culex modestus Ficalbi Diptera; Culicidae. Ann Inst Pasteur (Paris). 1970;118:839-55.

15. Balenghien T, Fouque F, Sabatier P, Bicout DJ. Horse-, bird-, and humanseeking behavior and seasonal abundance of mosquitoes in a West Nile virus focus of southern France. J Med Entomol. 2006;43:936-46.

16. Schaffner F, Angel G, Geoffroy B, Hervy JP, Rhaiem ABJ. Les moustiques d'Europe. Logiciel d'identification et d'enseignement. CD-ROM. Montpellier, France: Institut de Recherche pour le Développement/EID Méditerranée; 2001.

17. Hutchinson RA, West PA, Lindsay SW. Suitability of two carbon dioxidebaited traps for mosquito surveillance in the United Kingdom. Bull Entomol Res. 2007;97:591-7

18. Medlock JM, Vaux AGC. Seasonal dynamics and habitat specificity of mosquitoes in an English wetland - Implications for UK wetland management and restoration. J Vector Ecol. 2012. In press

19. Linke S, Ellerbrok H, Niedrig M, Nitsche A, Pauli G. Detection of West Nile virus lineages 1 and 2 by real-time PCR. J Virol Methods. 2007;146:355-8.

20. Jöst H, Bialonski A, Maus D, Sambri V, Eiden M, Groschup MH, et al. Isolation of Usutu virus in Germany. Am J Trop Med Hyg. 2011;85:551-3.

21. Medlock JM, Vaux AGC, Gibson G, Hawkes FM, Cheke RA. Potential vector for West Nile virus prevalent in Kent. Vet Rec. 2014;175:284-5.

22. Hutchinson RA, Lindsay SW. Perceived nuisance of mosquitoes on the Isle of Sheppey, Kent, UK. J Biosoc Sci. 2006;38:707-12.

23. Ponçon N, Balenghien T, Toty C, Baptiste Ferré J, Thomas C, Dervieux A, et al. Effects of local anthropogenic changes on potential malaria vector Anopheles hyrcanus and West Nile virus vector Culex modestus, Camargue, France. Emerg Infect Dis. 2007;13:1810-5.

24. Votýpka J, Seblová V, Rádrová J. Spread of the West Nile virus vector Culex modestus and the potential malaria vector Anopheles hyrcanus in central Europe. J Vector Ecol. 2008;33:269-77. 
25. Bødker R, Klitgård K, Byriel DB, Kristensen B. Establishment of the West Nile virus vector, Culex modestus, in a residential area in Denmark. J Vector Ecol. 2014:39:1-3.

26. Jourdain E, Olsen B, Lundkvist A, Hubálek Z, Sikutová S, Waldenström J, et al. Surveillance for West Nile virus in wild birds from northern Europe. Vector Borne Zoonotic Dis. 2011;11:77-9.

Submit your next manuscript to BioMed Central and take full advantage of:

- Convenient online submission

- Thorough peer review

- No space constraints or color figure charges

- Immediate publication on acceptance

- Inclusion in PubMed, CAS, Scopus and Google Scholar

- Research which is freely available for redistribution 